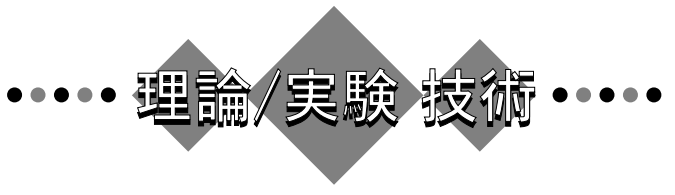

\section{プロファイル比較法FORTEを利用し たタンパク質立体構造予測}

産業技術総合研究所生命情報科学研究センター

富井健太郎

\section{1. はじめに}

構造既知タンパク質と配列類似性が検出されなかっ たタンパク質でも，その構造を解いてみると既知構造 と何らかの類似性を有する割合が多いことが知られて いる ${ }^{1)}$.こうした状況を踏まえると, 既知構造を利用し たタンパク質立体構造予測の適用可能範囲は, 非常に 大きいことが期待される. プロファイル比較法は, こ の適用範囲を効果的に拡大するものとして近年期待を 集めて打り，手法の改良もさかんに行われている。本 稿では, 予測対象タンパク質と既知立体構造との類似 性を検出するために開発されたプロファイル比較法 FORTEについて紹介する. また，2004年に開催された 立体構造予測実験 CASP6 ${ }^{2)}$ の結果一特に PSI-BLAST ${ }^{3)}$ を用いても類似性を検出できなかったタンパク質のカ テゴリーであるフォールド認識とよばれる部門での結 果一を例として, FORTEを利用したタンパク質立体構 造予測の実際について紹介する.

\section{2. アミノ酸配列の情報解析とタンパク質立体構 造予測}

\section{1 既知立体構造を用いた予測における問題点}

タンパク質の既知立体構造を鋳型として利用する構 造予測 (比較モデリング4) では, 予測対象配列とその 鋳型となる構造既知タンパク質のアミノ酸配列との正 確なアラインメントが与えられていることが大変重要 である. 局所配列比較法と問いあわせ配列のプロファ イルとを逐次的に組みあわせたPSI-BLASTの類似配列 検出感度は, ペアワイズアラインメントを利用した検 索法に比べると非常に強力なものであるが, それでも 遠縁関係を見逃す割合が多い1).また，比較する配列相
互の同一残基率が低い場合，アラインメント精度の劣 化が報告されている5 ${ }^{5,6)}$. それゆえ, 既知立体構造を利 用した構造予測の有効性を一層高めるためには, 類似 構造検出能力と同時に, アラインメント精度もより優 れた手法の開発が期待されるのである.

\section{2 プロファイル比較法の登場}

プロファイルとは, 問いあわせ配列とその相同配列 とのマルチプルアラインメントから導出される位置特 異的なスコア行列である7). プロファイル対プロファイ ルアラインメント (以下, プロファイル比較) 法は, 問 いあわせ配列のプロファイルのみを用いて検索を行う PSI-BLASTよりも, 検出感度とアラインメント精度の 両方の観点からみて, さらに優れた手法であると考え られている.この理由として，1）問いあわせ配列と既 知配列の中間にある配列情報が, 比較されるプロファ イルの双方に含まれるために生じる効果. これは中間 配列検索法 (ISS 法) ${ }^{8)}$ のある程度の有効性を考えても 納得しやすい. 2) 類縁関係タンパク質から抽出された 進化的な情報（特徵的な配列パターン）相互を比較す ることで，より遠縁関係の検出が可能になる，という 点が考えられる.

プロファイル比較では, 比較されるプロファイルの 各サイトにおける出現頻度に応じたアミノ酸種毎のス コア (20 次元のベクトル) 相互の類似度が計算され, こ れがペアワイズアラインメントにおけるアミノ酸相互 の類似度スコアに相当する役割を担う。類似度の計算 には, 内積や, 相関係数, あるいは拡張された対数オッ ズスコアなどさまざまな方法の適用が提案されてい る ${ }^{9)-11)}$. プロファイル比較を最初に立体構造予測に応 用したRychlewski ら ${ }^{9)}$ をはじめ多くのグループが，プ ロファイル比較法は遠縁タンパク質同定に有効である という伝統的立場にたって抢り, 類縁関係タンパク質 内での保存的な配列パターンの特徵を比較するという 観点から, 内積や, 拡張された対数オッズスコアなど を採用している。 これに対して筆者は，アミノ酸置換 パターンは類縁関係に特異的なものだけではなく, 各 サイトの置かれた立体構造上の「環境」12)にもおおい に依存すると考え, 保存的な部位以外の比較も構造類 似性の認識には重要であるという立場から, 相関係数 を採用している. また, 実利的な面で, 例えば内積と 比較した場合, 類縁関係の認識感度の上昇 (Fig. 1) や, 他のさまざまな類似度の計算方法と比較しても立体構 造類似性の検出能力が高く, 同一残基率が低い場合で

\title{
Protein Structure Prediction Using a Profile-Profile Comparison Method: FORTE
} Kentaro TOMII

Computational Biology Research Center, National Institute of Advanced Industrial Science and Technology 
(a)

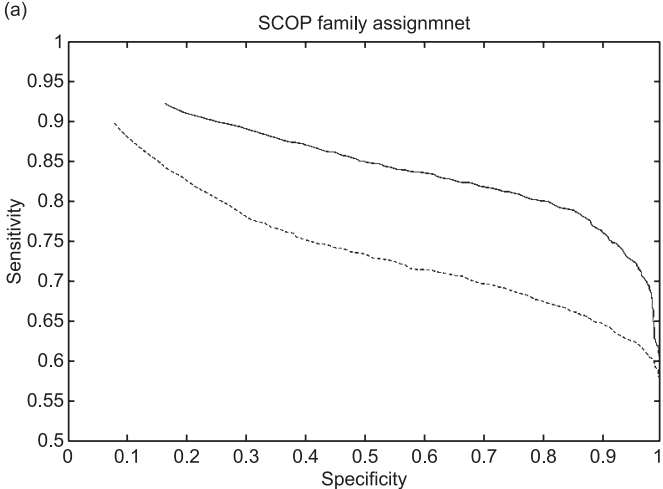

(b)

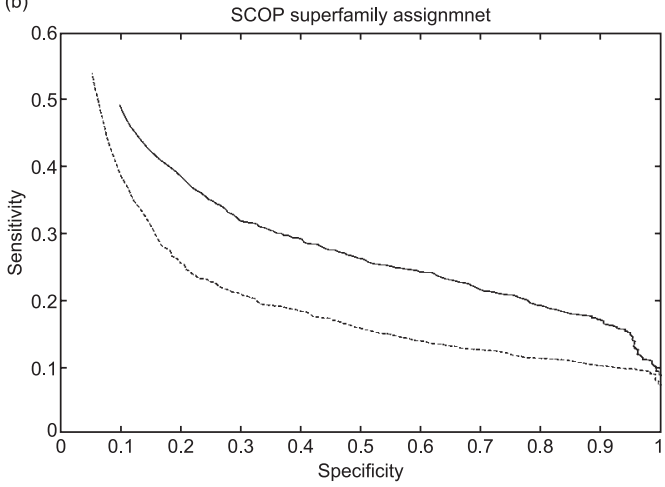

Fig. 1 Results for remote homology detection using correlation coefficients (thin line) and inner products (dotted line) are plotted in terms of specificity (TP/(TP+FP)) vs. sensitivity $(T P /(T P+F N))$. TP: true positive, $F P$ : false positive, $F N$ : false negative. Search results are shown (a) at the SCOP family level and (b) at the SCOP superfamily level. The dataset that was used for the benchmarks contains 948 protein single domains derived from the SCOP database using a $30 \%$ sequence identity cutoff and a resolution of $2.5 \AA$ or better.

もアラインメント精度が比較的良好10) であるというメ リットがあるものと考えている。 ただし，アラインメ
ント精度に有意な差はないとする報告もある ${ }^{13)}$.

\section{FORTEを用いたタンパク質立体構造予測}

\subsection{FORTEの概要}

FORTE は, タンパク質立体構造類似性検索のために 開発されたプロファイル比較法であり, Fold Recognition Techniqueを略して命名された. FORTEでは, 予測対象 タンパク質のプロファイルを問いあわせとする構造類 似性検索が，次に示す手順で実行される.

（0）比較するプロファイルの作成

構造既知ライブラリのタンパク質プロファイルおよ び予測対象タンパク質のプロファイルは，おもにPSIBLAST と NCBI のNR データベースを利用して作成さ れる. この工程の詳細は, 後述のように手法により異 なる. 既知構造ライブラリのタンパク質セットは, 立 体構造分類データベース $\mathrm{SCOP}^{14)}$ から相互の配列同一 残基率が 40\%を超えないよう選択された代表ドメイン におもに依存している。

(1) プロファイル相互の最適アラインメントとそのス コアの計算

プロファイル相互のアラインメント作成には, 動的 計画法が用いられる. 経験的にある程度最適化された アフィンギャップペナルティーを使用し, N-とC-両末 端のギャップにはペナルティーを課さない. プロファ イルサイト間の類似性尺度には, 相関係数を採用した.

（2）アラインメントスコアの統計的有意性の推定

（1）の方法によりライブラリ全体に対する検索が行 われた後, 個々のアラインメントスコアに対するZ-score が計算され, 統計的有意性が評価される. Z-scoreの計 算には，残基長の対数に応じたスコア補正が用いられ る.

CASP6への参加にあたり, 既知構造情報の立体構造 予測へのさらなる利用を目的として, 最初に開発した FORTE1 とは異なる複数のプロファイル構築法を利用し た手法を開発した．各々のプロファイル構築に用いた

Table 1 Profile construction methods of the FORTE series

\begin{tabular}{cll}
\hline Versions of FORTE & \multicolumn{1}{c}{ Query proteins } & Library proteins with known structures \\
\hline FORTE1 & PSI-BLAST & PSI-BLAST \\
FORTE2 & PSI-BLAST & FORTE1+PSI-BLAST \\
FORTE1T & T-Coffee+PSI-BLAST & T-Coffee+PSI-BLAST \\
FORTE-H & PSI-BLAST (for sequence profile) & PSI-BLAST (for sequence profile) \\
& PSIPRED (for structural profile) & FORTE1 (for structural profile) \\
FORTE-SS & PSI-BLAST+sliding window & PSI-BLAST \\
\hline
\end{tabular}

Names of profile-profile comparison methods are designated in the first column. The profile construction methods for query proteins are shown in the second column and for library proteins in the last column. 


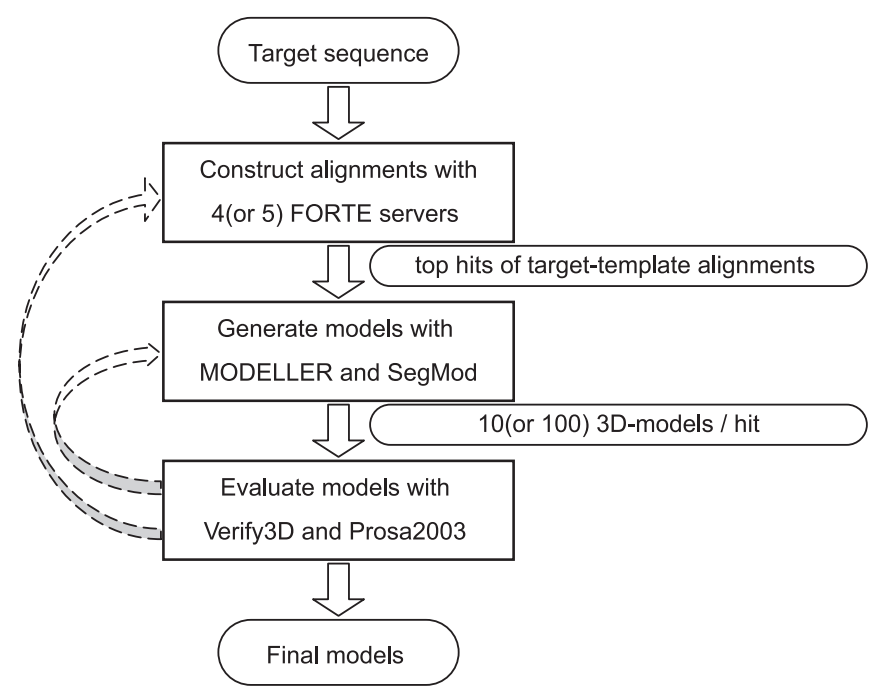

Fig. 2 Flowchart of our prediction protocols in CASP6.

手法は, Table 1 にまとめた通りである. FORTE1 15) で は, 予測対象と, 構造既知タンパク質の双方について, PSI-BLASTにより作成される配列プロファイルが使用 される. FORTE2では, FORTE1により検出された構造 類似タンパク質の情報をライブラリのプロファイル構 築時に取りこむことで, さらなる検出能力の向上を図っ た. FORTE1Tでは, アラインメント精度のさらなる向 上を目指し, プロファイル構築のためのシードとなる マルチプルアラインメントの作成に T-Coffee ${ }^{16)}$ を用い た. FORTE-Hでは, 配列情報だけでなく, 構造情報も 取り込み, 検出感度とアラインメント精度の向上を目 指した. FORTE-SSでは, 予測対象プロファイルをさま ざまな長さのスライディングウィンドウを用いて分割 し，上記 4 手法では見いだすことが困難な局所的類似 性の発見を目的とした.

CASP6でのFORTEを用いた構造予測のおもな手順 ${ }^{17}$ は, Fig. 2 および以下に示す通りである.

(1) FORTEの 4 手法を用い, 予測配列と構造既知夕 ンパク質とのアラインメントを計算する. 通常 Z-score が 8 以上のものが得られれば，それらすべてを次の構 造モデル構築の過程で用いた．経験的に得られたこの 閾值以上であると, 正確なアラインメントが得られて いる確率が高い. Z-scoreが 8 に満たない場合, 得られ た上位各100のアラインメントを次の過程で用いた. こ の場合, FORTE-SSによる計算も行った.

(2)（1）で得られたアラインメントにもとづき，構 造モデルの構築を行う. 1つのアラインメントあたり 10 （場合により100）個のモデルを構築する.

(3) 構築した全モデルについて, 統計的ポテンシャ
ル 12),18)を用いて検証とその順位づけを行い, 最終的に 提出する予測構造の選択を行った.

\subsection{CASP6への参加とその結果}

タンパク質立体構造予測法の発展と, 客観的評価の 場の提供を目的として, 1994 年より 2 年に一度, CASP (Critical Asssessment of Techniques for Protein $\underline{\text { Structure }}$ Prediction）とよばれる大規模な立体構造予測実験が開 催されている. CASP は, 立体構造解析がある程度進行 しているが, 当該時点で構造未知のタンパク質から予 測対象が選ばれ（というよりむしろ, 実験者の好意に より問題として提供され), 構造解析実験の終了まで に予測結果を提出するという形式で行われている. 第 6回目の構造予測実験CASP6は2004年に開催された ${ }^{19)}$.

CASPでは各問題につき, 提出者自身が優先順位をつ けた上で最大 5 個までの予測モデルの投稿が可能であ るが, FR/H (Fold Recognition/ㅌomology) 部門では基本 的に第 1 モデルのみが評価の対象となった. 相異なる 特徵をもつ6つの立体構造比較法を用いて, 問題毎に, 各グループが提出した予測構造モデルと実際に解かれ た立体構造との類似度が計算された。 この類似度にも とづく相対的評価值の, 全 23 問での総和と平均が最終 評価に用いられた，実際に解かれた構造とわれわれの 予測した構造との比較結果は, Table 2 にまとめた通り である. 現状では, FR/H部門の約 $3 / 4$ のンパク質に ついて, 少なくとも4割を超える残基について, $\mathrm{C}_{\alpha} \mathrm{RMSD}$ が $2 \sim 3 \AA$ 程度の精度のモデル構築が可能であることが わかる（表中の網掛け部分）。他グループとの相対的 な比較では, 第3 位という評価を受けた。 またフォー ルド認識部門全体でも, 第 4 位という結果であった ${ }^{20)}$. 
Table 2 Summary of Predictions for FR/H Targets

\begin{tabular}{|c|c|c|c|}
\hline Target & Length & $\%$ & RMSD \\
\hline T0197 (1xkc) & $30 / 166$ & 18 & $2.98 / 13.61$ \\
\hline T0199_2(1stz) & $60 / 134$ & 45 & $3.34 / 15.37$ \\
\hline T0202_1(1suw) & $66 / 123$ & 54 & $2.56 / 5.85$ \\
\hline T0203（1vkp） & $172 / 365$ & 47 & $2.65 / 10.93$ \\
\hline T0206 (2cuo) & $24 / 138$ & 17 & $2.96 / 15.49$ \\
\hline T0213 (1te7) & $65 / 103$ & 63 & $2.25 / 5.87$ \\
\hline T0214（1s04） & $65 / 110$ & 59 & $2.70 / 4.85$ \\
\hline T0222_2(1vli) & $61 / 64$ & 95 & $1.49 / 1.67$ \\
\hline T0223_2(1vkw) & $79 / 92$ & 86 & $2.26 / 3.30$ \\
\hline T0224 (1rhx) & $71 / 87$ & 82 & $2.39 / 4.04$ \\
\hline T0227（1wk2） & $50 / 84$ & 60 & $2.32 / 13.46$ \\
\hline T0228_1 (1vlp) & $68 / 157$ & 43 & $2.45 / 11.73$ \\
\hline T0228_2(1vlp) & $102 / 235$ & 43 & $2.66 / 33.72$ \\
\hline T0237_1 (1w8k) & $13 / 153$ & 8 & $2.93 / 16.03$ \\
\hline T0237_2(1w8k) & $11 / 99$ & 11 & $2.32 / 11.58$ \\
\hline T0237_3(1w8k) & $7 / 54$ & 13 & $2.53 / 5.73$ \\
\hline T0239 (1rki) & $25 / 98$ & 26 & $2.54 / 15.78$ \\
\hline T0243 & $64 / 88$ & 73 & $2.61 / 5.16$ \\
\hline T0249_1(1t6s) & $42 / 73$ & 58 & $2.82 / 6.89$ \\
\hline T0249_2(1t6s) & $62 / 77$ & 81 & $2.13 / 4.18$ \\
\hline T0251 (1xg8) & $52 / 99$ & 53 & $2.90 / 5.69$ \\
\hline T0262_2(1wfx) & $49 / 97$ & 51 & $1.77 / 9.18$ \\
\hline T0263（1wd6） & $84 / 97$ & 87 & $1.98 / 4.54$ \\
\hline
\end{tabular}

The first column shows CASP identifiers of FR/H targets. The PDB identifiers of the targets are indicated in parentheses. The T0243 structure has not been made publicly available, yet. The second column shows the number of structurally equivalent residues between our first models and the native structure of targets, and the number of residues of the targets. Structurally equivalent residues are determined after superposition with a $5 \AA$ equivalence cutoff. The third column presents numbers correspond to a fraction of structurally equivalent residues. The last column lists values of $\mathrm{C}_{\alpha} \mathrm{RMSD}$ of structurally equivalent residues between our model and the native structure, and $\mathrm{C}_{\alpha}$ RMSD of whole residues. Rows of targets for which we can provide "accurate" (see text) models are shaded.

もちろんこの結果は合理的だが, 問題に応じた不定形 な人的判断の介入に依る部分もある. しかし，結果の 多くの部分において, 自動化された手法の重要性が確 認されている ${ }^{17,20)}$.

\section{3 結果の検討と今後の課題}

われわれの予測手法は, プロファイル比較にもとづ くアラインメント作成と, それらにもとづく構造モデ ルの網羅的構築，そして一般に普及している統計ポテ ンシャルを用いた構造評価関数によるモデルのスクリー ニングという非常に単純な手順ではあるが, 既知構造

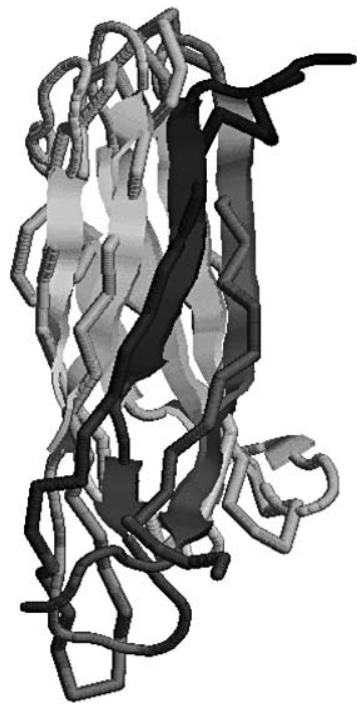

Fig. 3 Our first model (ribbon) and native structure (thick line) for the FR/A target, T0212(1tza).（カラー図は電 子ジャーナル http://www.jstage.jst.go.jp/browse/biophys/ 参照）

を利用した予測法として非常に有効なものであること が裏づけられたといえよう.この原因の1つとして, プ ロファイルサイト相互の類似度の計算に, 相関係数を 用いたことがあげられるかもしれない.すでに述べた ように, 相関係数を用いることで, 他の類似度計算法 と比較して, 類似性検出能力とアラインメント精度の 向上を期待した。しかし実際には, プロファイル比較 による予測精度は, 類似度の計算法以外のさまざまな 要因（マルチプルアラインメントの作成法, プロファ イルスコアの計算法, 既知構造ライブラリとして使用 するタンパク質のセット，など）により影響を受け得 る. よって, 筆者の作業仮説の妥当性と予測精度のさ らに厳密な検証は, 追求されるべき重要な課題である.

次に, 統計ポテンシャルを用いた構造評価関数によ る候補モデルの選択がうまく機能したことがあげられ る. その典型例が, FR/A (Fold Recognition/Analogy) 部 門の問題の 1 つである T0212 に対する予測結果であ る ${ }^{21)}$. この問題では, 統計的に有意な (Z-scoreが 8 以 上の）アラインメントは得られず, 5 種類の FORTE法 で得られた上位各々 100 (合計 500) アラインメントに もとづきモデル構築を行い, その中から統計的ポテン シャルを用いて候補構造の選択を行うことで正確なモ デル（全長の $60 \%$ 以上に相当する 76 残基について $\mathrm{C}_{\alpha}$ RMSDが3.0 A; Fig. 3) を予測することができた。 この 結果は, 主要なコンセンサス予測サーバが提示してい た，予測信頼度の低い，本来の構造とは異なるトポロ 
ジーを有するタンパク質にもとづくモデルを，ほとん どのグループが提出していたのと対照をなすものであっ た。このように, 統計ポテンシャルを用いた候補構造 モデルの選択は概してうまく機能したものの, 細部を 観察するとかならずしも最良モデルを選択できていた わけではないことから, 改善の余地があると考えてい る.

構築した 5 種類のプロファイル比較法の予測結果に は, 予測問題全体の統計をとると劇的な差はない。し かし 0212 の例にみられるように, 異なるプロファイ ル比較法を利用することで，予測対象タンパク質と既 知構造との類似性について検出可能な範囲を拡大, あ るいはより精度のよいアラインメントを提供すること ができたものと考えられる。 このような好結果が得ら れる一方で，フォールド認識部門でわれわれより上位 に位置したグループが，予測対象と相同なタンパク質 についての予測結果のコンセンサス情報を最終的な予 測に使用していたことを考えると，この方向での発展 も今後取りくむべき課題であろう.

\section{4. おわりに}

今回紹介したような鋳型構造を利用したタンパク質 立体構造予測法によって未知タンパク質の立体構造モ デルが提供されることで, 構造類似性の観点からの類 縁関係の推定や，活性部位の推定・比較などがある程 度可能になるものと考えられる ${ }^{22}$. また今後, より精 密な構造モデルの提供が可能になれば, 分子動力学計 算やドッキング計算の初期構造, あるいはX線結晶構 造解析の分子置換法の参照分子モデルとして使用され ることにもなるかもしれない

現在, http://www.cbrc.jp/forte/において FORTE1 サー ビスの公開 (学術研究利用に限る. それ以外の場合は, 別途ライセンス契約が必要）を行っている15. 予測対 象タンパク質のアミノ酸配列をFASTAフォーマットで 入力すると, 統計的有意水準の厳しいものから順に, 問 いあわせ配列とライブラリに含まれる構造既知タンパ ク質とのアラインメント上位 20 ガユーザーに返答され る.

\section{謝 辞}

CASP6に抢ける立体構造予測は, 当研究センターの 広川貴次チームリーダー, 本野千恵研究員との共同研
究によるものです，深甚なる謝意を表します，また執 筆の機会を頂き，感謝致します。

\section{文 献}

1) Brenner, S. E. and Levitt, M. (2000) Protein Science 9, 197-200.

2) http://predictioncenter.org/

3) Altschul, S. F., Madden, T. L., Schäffer, A. A., Zhang, J., Zhang, Z., Miller, W. and Lipman, D. J. (1997) Nucleic Acids Res. 25, 3389-3402.

4) Fiser, A. and Sali, A. (2003) Methods Enzymol. 374, 461491.

5) Sauder, J. M., Arthur, J. W. and Dunbrack, R. L., Jr. (2000) Proteins 40, 6-22.

6) Elofsson, A. (2002) Proteins 46, 330-339.

7) Eidhammer, I., Jonassen, I. and Taylor, W. R. (2004) Protein Bioinformatics: An Algorithmic Approach to Sequence and Structure Analysis, pp. 123-140, John Wiley $\&$ Sons Ltd., West Sussex.

8) Park, J., Teichmann, S. A., Hubbard, T. and Chothia, C. (1997) J. Mol. Biol. 273, 349-354.

9) Rychlewski, L., Jaroszewski, L., Li, W. and Godzik, A. (2000) Protein Science 9, 232-241.

10) Wang, G. and Dunbrack, R. L., Jr. (2004) Protein Science 13, 1612-1626.

11) Ohlson, T., Wallner, B. and Elofsson, A. (2004) Proteins 57, 188-197.

12) Lüthy, R., Bowie, J. U. and Eisenberg, D. (1992) Nature 356, 83-85.

13) Edgar, R. C. and Sjolander, K. (2004) Bioinformatics 20, 1301-1308.

14) http://scop.mrc-lmb.cam.ac.uk/scop/

15) Tomii, K. and Akiyama Y. (2004) Bioinformatics 20, 594595.

16) Notredame, C., Higgins, D. and Heringa, J. (2000) J. Mol. Biol. 302, 205-217.

17) Tomii, K., Hirokawa, T. and Motono, C. (2005) Proteins 61, 114-121.

18) Sippl, M. J. (1993) Proteins 17, 355-362.

19）千見寺浄慈, 高田彰二, 本野千恵, 富井健太郎 (2005) 生物物理 45, 165-167.

20) Wang, G., Jin, Y. and Dunbrack, R. L., Jr. (2005) Proteins 61, 46-66.

21) Vincent, J. J., Tai, C., Sathyanarayana, B. K. and Lee, B. (2005) Proteins 61, 67-83.

22) Watson, J. D., Laskowski, R. A. and Thornton, J. M. (2005) Curr. Opin. Struct. Biol. 15, 275-284. 
プロファイル比較法FORTE を利用したタンパク質立体構造予測

富井健太郎（とみい けんたろう）

産業技術総合研究所生命情報科学研究センター研究員

連絡先: $\mathbf{T} 135-0064$ 東京都江東区青海 2-42

E-mail: k-tomii@aist.go.jp 